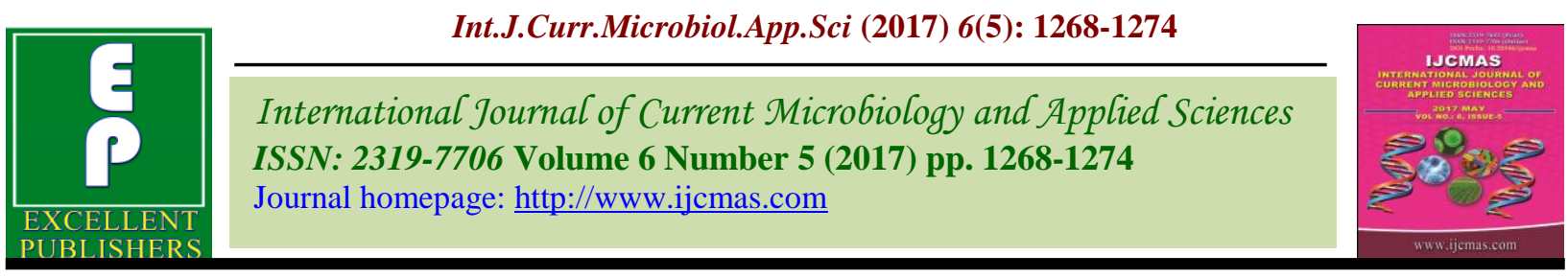

Original Research Article

https://doi.org/10.20546/ijcmas.2017.605.137

\title{
Biological Treatment of Banana Pseudostem Fibre: Effect on Softening and Mechanical Properties
}

\author{
Mageshwaran Vellaichamy* and Parnavi Vijay Gaonkar \\ ICAR- Central Institute for Research on Cotton Technology, Mumbai-400019, India \\ *Corresponding author
}

\begin{tabular}{|c|c|}
\hline & A B S T R A C T \\
\hline $\begin{array}{l}\text { Ke y w o r d s } \\
\text { Aspergillus niger, } \\
\text { Banana fibre, } \\
\text { Crude enzyme, } \\
\text { Mechanical } \\
\text { property, Softening. }\end{array}$ & \multirow{3}{*}{$\begin{array}{l}\text { Banana pseduostem fibre or banana fibre is one of the emerging natural fibres having } \\
\text { potential industrial application. The softening of these fibres could improve its mechanical } \\
\text { properties and thus widen its textile applications. The present study was aimed at softening } \\
\text { of banana fibres using enzyme extract of Aspergillus niger. The polygalactouronase and } \\
\text { lignin peroxidise activity in enzyme extract was found to be } 25 \text { and } 0.153 \mathrm{U} / \mathrm{ml} \\
\text { respectively. The banana fibres were subjected for biological softening by enzyme } \\
\text { treatment }(2 \text { and } 4 \mathrm{~h}) \text {, culture treatment }(48 \text { and } 72 \mathrm{~h}) \text { and anaerobic treatment ( } 72 \text { and } \\
168 \mathrm{~h}) \text {.The evaluation of treated fibre for mechanical properties showed that tenacity } \\
\text { (g/tex) was higher, } 28.4 \text { in anaerobic consortium treated }(168 \mathrm{~h}) \text { while, the average peak } \\
\text { elongation }(\%) \text { was found higher, } 2.9 \text { in aerobic crude enzyme treated }(2 \mathrm{~h}) \text { fibre. The } \\
\text { crude enzyme and anaerobic treatments were found to improve the surface smoothness of } \\
\text { banana fibre than the culture treatment under phase contrast microscopic observations. }\end{array}$} \\
\hline Article Info & \\
\hline $\begin{array}{l}\text { Accepted: } \\
\text { 12 April } 2017 \\
\text { Available Online: } \\
\text { 10 May } 2017\end{array}$ & \\
\hline
\end{tabular}

\section{Introduction}

India is the largest producer of banana contributing to $27 \%$ of the world production (Mohapatra et al., 2010). The area under cultivation of banana is $8.3 \mathrm{~m}$ ha. The pseudostem is the fibre yielding part of banana plant. More than fifty million tonnes of banana pseudostem is generated after harvest of banana plant from which 3.9 million tonnes of fibre could be extracted (Chauhan and Sharma et al., 2014). Banana pseudostem fibre is a lignocellulosic material mainly consists of polysaccharides with cellulose microfibrils (50-60\%) embedded with hemicelluloses (25-30\%), lignin (12-18 $\%)$, pectin (3-5\%), water soluble material (2-3 $\%)$, wax and fat (3-5\%) and ash (1-1.5\%) (Mohiuddin et al., 2014). Banana fibre exhibits better reinforcing efficiency and have good durability, strength and resistance to environmental factors like temperature and moisture. Due to the highs cost of synthetic fibres like glass, carbon or plastics and also health hazards caused by asbestos fibres, banana fibres are gaining importance in the international markets as they pose no toxic effects to man and the environment. The softened banana fibres have application as reinforcement in polymer composites, packaging, automobiles, interiors and storage devices. The methods such as mechanical, chemical and biological treatments are followed for extraction of banana fibres. Extraction is a process of separation (decortications) of non-fibrous plant tissues 
and other cementing material from the fibre bundles. In mechanical extraction, 15 to $20 \mathrm{~kg}$ of banana fibre could be recovered in a day compared to $500 \mathrm{~g}$ a day through laborious manual process (Das et al., 2010). The chemicals such as sodium hydroxide, ammonium oxalate or sodium sulphite are used for removal of non-fibrous extraneous materials in chemical extraction of banana fibre. In biological treatment, microbial and enzymatic retting is used for fibre extraction. In microbial retting, The pseudostem are suspended in water containing microbial consortia at least for seven days while in enzymatic retting, enzymatic solution containing polygalactouronase, pectin methyl esterase are used for extraction of fibre. Of the different fibre extraction methods, biological treatment resulted in higher fibre yield and the quality of fibre was better due to more evenness and lustre in the fibre. However, due to higher capacity and productivity, mechanical extraction is widely practiced. Thus, the present study was aimed to evaluate the effect of biological treatment on improvement of softening and mechanical properties of mechanically extracted banana fibre.

\section{Materials and Methods}

\section{Banana fibre}

The mechanically extracted banana fibre were obtained from Navsari Agricultural University (NAU), Gujarat was used for experimental purpose. The fibres cut into 20 $\mathrm{cm}$ length were used for biological treatment.

\section{Microorganisms}

The test microbial strain, Aspergillus niger was obtained from Microbiology Laboratory of ICAR-Central Institute for Research on Cotton Technology (CIRCOT), Mumbai. The culture was grown in Potato Dextrose Broth at
$28 \pm 2{ }^{\circ} \mathrm{C}$ for $48 \mathrm{~h}$ under static condition. The culture was preserved in Potato Dextrose Agar slant at $4^{\circ} \mathrm{C}$. The anaerobic consortium maintained at ICAR-CIRCOT, Mumbai was used for anaerobic treatment.

\section{Extraction of crude enzyme}

One percent of $48 \mathrm{~h}$ old culture $A$. niger was transferred into sterile $100 \mathrm{ml}$ mineral medium ( $\left(\mathrm{NH}_{4}\right)_{2} \mathrm{SO}_{4}-1.4 \mathrm{~g}, \mathrm{~K}_{2} \mathrm{HPO}_{4}-6 \mathrm{~g}$, $\mathrm{MgSO}_{4} \cdot 7 \mathrm{H}_{2} \mathrm{O}-0.1$ g, D.W-1 litre, $\mathrm{pH}$ 6.0) containing $0.5 \%$ citrus pectin and $0.5 \%$ lignin and incubated in rotary shaker (150 $\mathrm{rpm})$ at $30^{\circ} \mathrm{C}$ for five days. The enzyme extract was separated by filtration followed by centrifugation at $10,000 \mathrm{rpm}$ for $10 \mathrm{~min}$ and stored at $4^{\circ} \mathrm{C}$ until use.

\section{Estimation of polygalactouronase (PGA) and lignin peroxidise (LiP)}

\section{Polygalactouronase activity}

The PGA activity in crude enzyme was determined by measuring the amount of reducing sugar released from citrus pectin. The reaction mixture consisted of $0.5 \mathrm{ml}$ substrate buffer $(0.1 \mathrm{~g}$ pectin in $10 \mathrm{ml}$ of 0.1 $\mathrm{M}$ acetate buffer, $\mathrm{pH} 6.0$ ) and $0.5 \mathrm{ml}$ of crude enzyme solution. The mixture was incubated at $40^{\circ} \mathrm{C}$ in water bath for $10 \mathrm{~min}$ and the reaction was stopped by using $1 \mathrm{ml}$ of DNSA reagent. The mixture was kept in boiling water bath for $5 \mathrm{~min}$. The absorbance was read at $595 \mathrm{~nm}$. One unit of enzyme activity $(\mathrm{U} / \mathrm{ml})$ was defined as one $\mu \mathrm{mol}$ of galactouronic acid released per min (Silva et al., 2002).

\section{Lignin peroxidase}

The LiP in crude enzyme was determined based on demethylation of methylene blue dye. The reaction mixture consisted of $4.4 \mathrm{ml}$ of crude enzyme extract, $0.2 \mathrm{ml}$ of $1.2 \mathrm{mM}$ 
methylene blue and $1.2 \mathrm{ml}$ of $0.5 \mathrm{M}$ of sodium tartrate buffer $(\mathrm{pH} 4.2)$.The reaction mixture was incubated for $10 \mathrm{~min}$ at $37^{\circ} \mathrm{C}$. The absorbance was measured at $664 \mathrm{~nm}$. A blank was run in which $4.4 \mathrm{ml}$ of distilled water was added in the place of crude enzyme. One unit of enzyme activity $(\mathrm{U} / \mathrm{ml})$ was defined as change in absorbance at 664 nm per min.

\section{Biological treatment}

In biological treatment, crude enzyme of $A$. niger, Culture of $A$. niger and Anaerobic culture were treated at different time period for softening of banana fibres. The treatment details are presented in table 1.

\section{Crude enzyme treatment}

Five ml of crude enzyme extract was added in $95 \mathrm{ml}$ distilled water in a conical flask. To which, $1 \mathrm{~g}$ of raw fibres was placed using sterile forceps. The flask was covered with the aluminium foil. The fibres were subjected to treatment for $2 \mathrm{~h}$ (T1) and $4 \mathrm{~h}$ (T2) respectively (Table 1). After treatment, the fibres were taken out and slowly washed under tap water. The fibre was allowed to air dry on filter paper. The dry combed fibres were analyzed for mechanical and microscopic characterization.

\section{Culture treatment}

Five percent inoculum of $48 \mathrm{~h}$ old culture of A. niger was transferred into a flask containing sterile $100 \mathrm{ml}$ of mineral medium ( $\mathrm{pH}$ 6.0) containing $0.5 \%$ glucose and incubate in rotary shaker $(150 \mathrm{rpm})$ at $30^{\circ} \mathrm{C}$ for $24 \mathrm{~h}$. One $\mathrm{g}$ of mechanically extracted banana fibre was aseptically placed into the flask with the help of sterile forceps. The flaks were further incubated for $48 \mathrm{~h}$ (T3) and $72 \mathrm{~h} \mathrm{(T4)}$ at room temperature under stationary condition (Table 1). After treatment, the fibres were air dried, combed and analyzed for mechanical properties and microscopic evaluation as described earlier.

\section{Anaerobic treatment}

One g of raw banana fibre was placed into a flask containing $100 \mathrm{ml}$ of anaerobic consortium for $72 \mathrm{~h}$ (T5) and $168 \mathrm{~h}$ (T6) respectively at room temperature under stationary condition (Table 1). After treatment, the fibres were removed, air dried, combed and analyzed for mechanical properties and microscopic characterization as described earlier.

\section{Evaluation of mechanical properties}

The individual fibre was tested under Universal Testing Machine having $10 \mathrm{~kg}$ load scale capacity, guage length $50 \mathrm{mM}$ and speed $10 \mathrm{~mm} / \mathrm{min}$. Ten individual fibres were tested and the weight of ten fibres were noted for each treatment. The peak load and peak elongation of each fibre was noted. The raw untreated fibre was considered as control. The mechanical properties such as tenacity (g/tex) and young's modulus (kgf/mm) were also recorded.

\section{Microscopic characterization}

The untreated and treated banana fibres were observed under Phase contrast microscope (Nikon TE 2000) to evaluate the surface smoothness and evenness of the fibre. The evenness in the fibre was analyzed by calculating fibre thickness (diameter) at five different places using the $\mathrm{J}$ - image software.

\section{Results and Discussion}

Banana pseudostem fibre is gaining importance among the natural fibres in application of textile, packaging and composite due to its inherent properties such 
as UV protection, weather proof, moisture release and regain, biodegradability etc (Vigneswaran et al., 2015). By and large, mechanical extraction is practiced for separation and isolation of fibres from banana pseudostem due to its higher efficiency. The mechanically extracted fibre is having rough surface and more of unevenness in the fibre due to non-removal of pectin and lignin during the fibre extraction process. Mostly the extracted fibres are being degummed before any application like spinning or composite preparation. The softening of fibres could be done either through softening chemicals or enzymes. The enzymes used for softening of fibres are pectinase, cellulase and laccase. The microorganisms are the source for these softening enzymes. Aspergillus niger otherwise called common mold which is omnipresent in environment and a vigorous producer of softening enzymes namely pectinase, cellulase and laccase (Sarma and Deka, 2016). In the present study, the crude enzyme of $A$. niger was evaluated for its ability to soften the mechanically extracted banana psuedostem fibre.

Table.1 Treatment details for softening of banana fibres

\begin{tabular}{ll}
\hline Treatment & Feature \\
\hline T1 & Crude enzyme for $2 \mathrm{~h}$ \\
T2 & Crude enzyme for $4 \mathrm{~h}$ \\
T3 & Culture for $48 \mathrm{~h}$ \\
$\mathrm{~T} 4$ & Culture for $72 \mathrm{~h}$ \\
T5 & Anaerobic for $72 \mathrm{~h}$ \\
T6 & Anaerobic for $168 \mathrm{~h}$ \\
\hline
\end{tabular}

Table.2 Effect of biological treatment on mechanical properties of Banana fibre

\begin{tabular}{lllll}
\hline Treatments & $\begin{array}{l}\text { Peak load } \\
(\mathrm{g})\end{array}$ & $\begin{array}{l}\text { Peak elongation } \\
(\%)\end{array}$ & Tenacity (g/tex) & $\begin{array}{l}\text { Young's } \\
\text { modulus } \\
(\mathrm{kgf} / \mathrm{mm})\end{array}$ \\
\hline Crude enzyme for 2 h & 494 & 2.86 & 24.7 & 0.34 \\
Crude enzyme for 4 h & 445 & 2.30 & 22.3 & 0.43 \\
Culture for 48 h & 460 & 2.72 & 23.0 & 0.33 \\
Culture for 72 h & 474 & 2.10 & 23.7 & 0.43 \\
Anaerobic for 72 h & 528 & 1.86 & 26.4 & 0.56 \\
Anaerobic for 168 h & 568 & 1.42 & 28.4 & 0.80 \\
Control (untreated) & 673 & 1.9 & 24.0 & 0.70 \\
\hline
\end{tabular}


Fig.1 Effect of biological treatment on softening of Banana fibre (a.untreated (control), b-1. Crude enzyme for $2 \mathrm{~h}, \mathrm{~b}-2$. Crude enzyme for $4 \mathrm{~h}$, c-1. Culture for $48 \mathrm{~h}, \mathrm{c}-2$. Culture for $72 \mathrm{~h}, \mathrm{~d}-1$. Anaerobic for $72 \mathrm{~h}, \mathrm{~d}-2$.Anaerobic for $168 \mathrm{~h}$
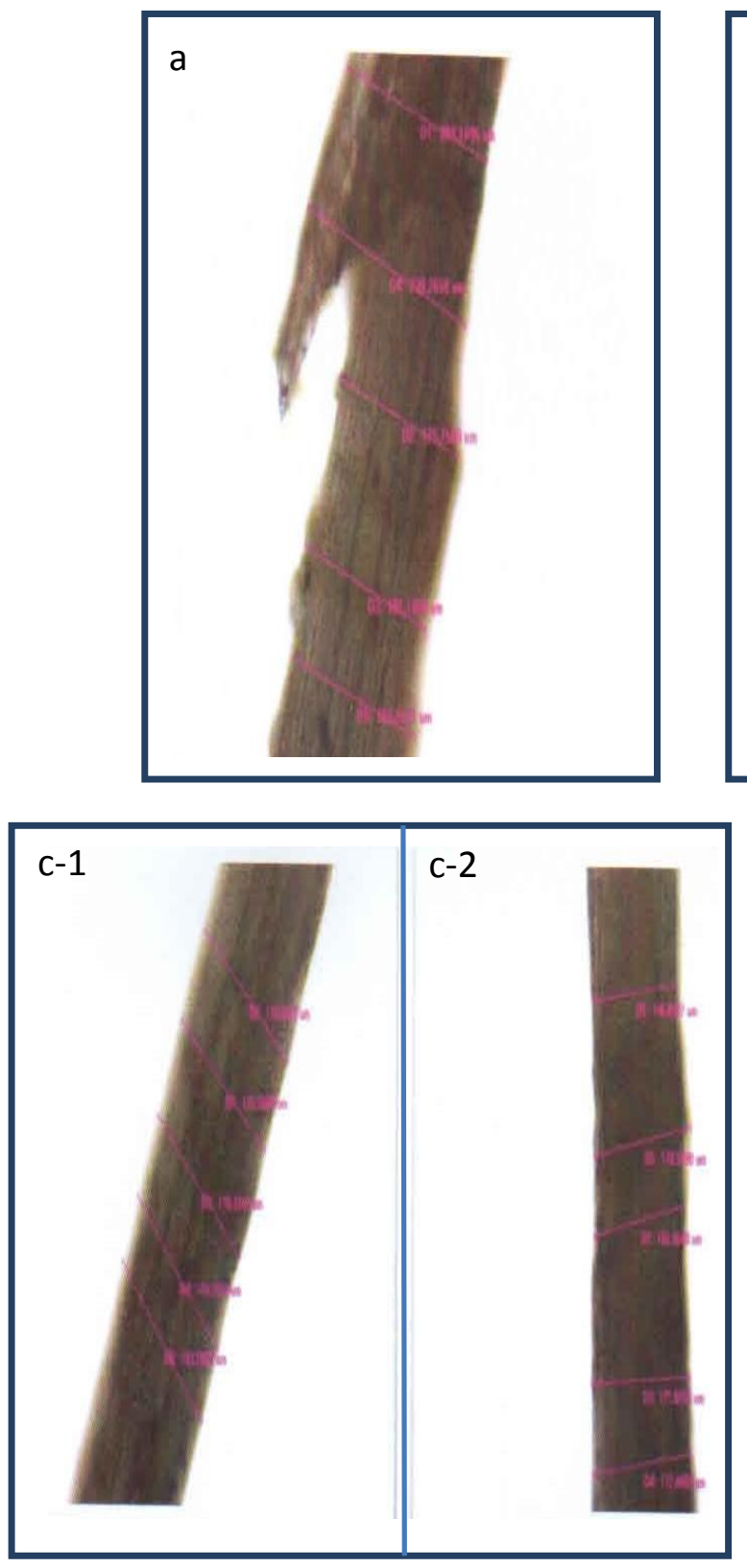

The mineral salt medium containing $0.5 \%$ of pectin and lignin respectively was used for production of crude enzyme. The polygalactouronase and lignin peroxidise activity in the enzyme extract was estimated and found to be 25 and $0.153 \mathrm{U} / \mathrm{ml}$ respectively. Similarly, Sarma and Deka, 2016 reported that polygalactouronase
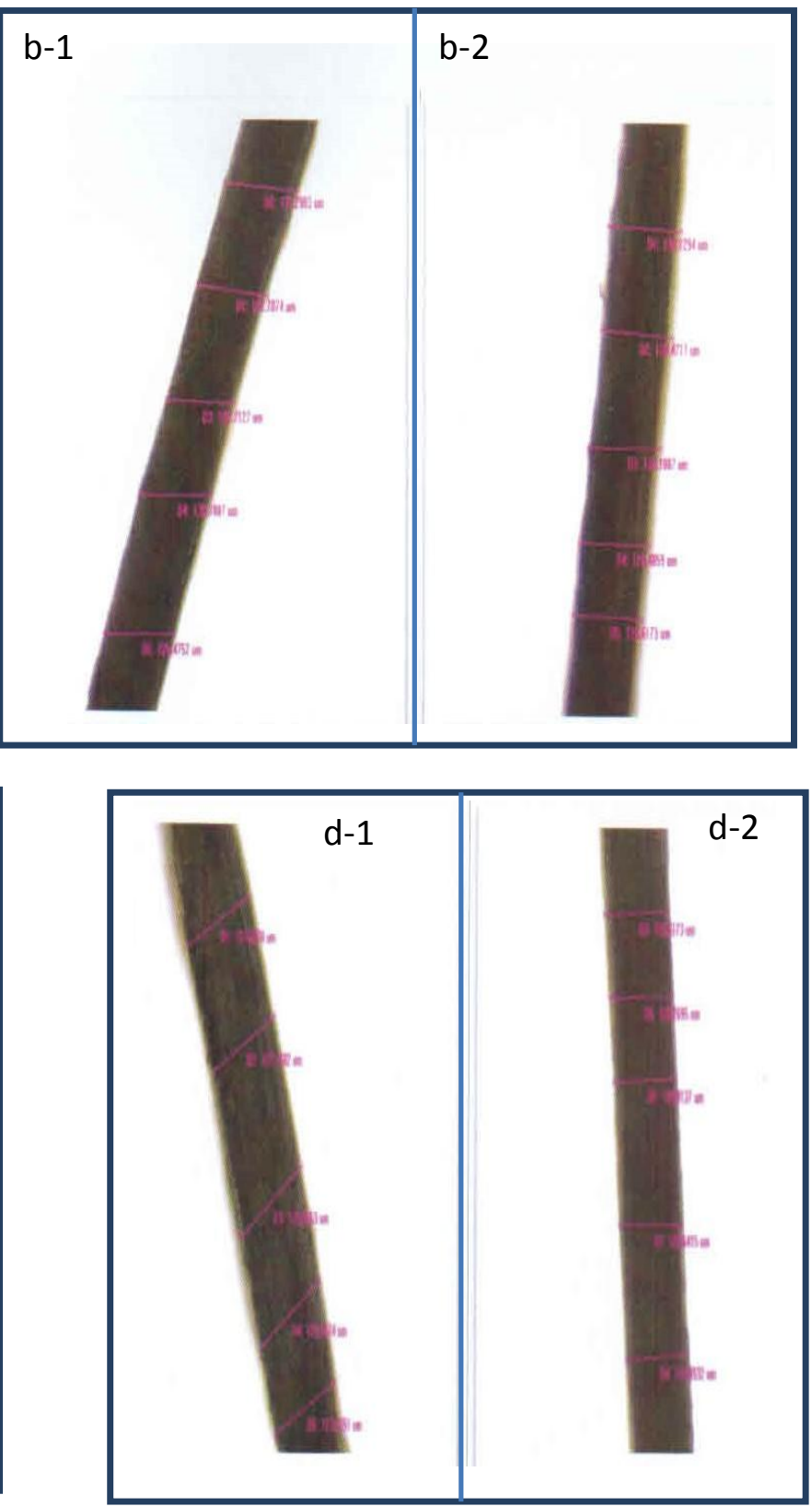

activity was $5.36 \mathrm{U} / \mathrm{g}$ in crude enzyme meant for softening of banana fibre. In the present study, the mechanically extracted fibre was subjected to different treatments viz., crude enzyme ( 2 and $4 \mathrm{~h}$ ), A. niger culture (48and $72 \mathrm{~h})$ and anaerobic (72 and $168 \mathrm{~h})$. The treated fibres were evaluated for its mechanical properties such as Peak load (g), 
Peak elongation (\%), Tenacity (g/tex) and Young's modulus $(\mathrm{kgf} / \mathrm{mm})$ and the results are presented in table 2. The peak load (g) was lower in treated fibres than untreated. The peak elongation percentage was higher (2.86) in crude enzyme $2 \mathrm{~h}$ treated fibre among the different treatments. The tenacity (g/tex) was higher in anaerobic treatment (168 h) followed by $72 \mathrm{~h}$. The corresponding values are 28.4 and 26.4 respectively. The young's modulus was higher in anaerobic treatment $(168 \mathrm{~h})$ whereas in other treatments, the values were lower than the untreated (control). The results are in agreement with previous study where the tenacity of $A$. niger crude enzyme treated banana fibre was 24.5 cN/tex (Sarma and Deka, 2016).

Under phase contrast microscopic observations, the treated fibres had entire and smooth fibre surface compared to untreated fibres. The distribution of fibre thickness (diameter) at five different places over the length was determined by $\mathbf{J}$ Image software. The thickness of the untreated fibre was distributed in wide range (175 to $240 \mu$ ) (Fig. 1a). The fibre diameter ranged from 121 to $131 \mu$ and 123 to $135 \mu$ was observed in crude enzyme 2 and $4 \mathrm{~h}$ treated fibre respectively [Fig. 1(b- 1 and b-2)]. The fibre diameter ranges from 175 to 195 and 158 to $180 \mu$ respectively in culture treatment of 48 and 72 $\mathrm{h}$ respectively (Fig. 1 (c-1 and c-2).The anaerobic treatment of fibre resulted in distribution of fibre diameter from 123 to 138 $\mu$ (Fig. 1 (d-1 and d-2)). The reduction in fibre thickness in treated fibre was due to action of degumming by enzymes (Sarma and Deka, 2016). The reduction in fibre thickness was higher in crude enzyme treatment followed by anaerobic treatment and culture treatment. The lower the distribution of fibre thickness over certain length, the better is the fibre evenness. The distribution of fibre thickness was lower in crude enzyme treatment followed by anaerobic treatment and culture treatment. In a similar study, Scanning Electron Microscope observations showed that the enzyme treated banana fibre was smoothen to some extent compared to untreated fibre (Shroff and Karolia, 2015).

In the present study, banana fibre was subjected to enzymatic treatment to improve its softening and mechanical properties. The results showed, anaerobic treated fibre $(168 \mathrm{~h})$ had better mechanical properties (tenacity and young's modulus). While, the softening of fibres evaluated under microscope showed, crude enzyme $2 \mathrm{~h}$ treated fibre had more evenness than other treatments. The crude enzyme treated ( $2 \mathrm{~h}$ ) fibre also had improved mechanical properties next to anaerobic treatment. In conclusion, considering the characteristics such as less treatment time and improved softening of fibre, crude enzyme (2 h) of $A$. niger would be an ideal treatment for improvement in softening characteristics of banana fibre.

\section{References}

Chauhan, S., Ad Sharma, A.K. 2014. Enzyme treatment in improving the quality of pseudostem fibre of banana plant to use this bioresource for making handmade paper. Int. J. Fiber and Textile Res., 4(3): 57-61.

Das, P.K., Nag, D., Debnath, S and Nayak, L.K. 2010. Machinery for extraction and traditional spinning of plant fibres. Indian J, Trad. Knowlede, 9(2): 386393.

Mohapatra, D., Mishra, S and Sutar, N. 2010. Banana and its by-product utilization: An overview. J. Scientific and Industrial Res., 69: 323-329.

Mohiuddin A.K.M., Saha, M.K., Hossain, M.S. and Ferdoushi, A. 2014. Usefulness of banana bio-products: A review. The Agriculturists, 12(1): 148158. 
Sarma, I. and Deka, A.C. 2016. Banana fibre extraction by mycogenic pectinase enzyme(s)- An eco-friendly approach. Imperial J. Interdisciplinary Res., 2(10): 997-1006.

Shroff, A. and Karolia, A. 2015. Biosoftening of banana fibre for non-woven application. Int. J. Scientific Res., 4(4): 524-527.

Silva, D., Martins, E.D.S., Silva, R.D and
Gomes, E. 2002. Pectinase production by Penicillum viridcatum RCF-3 by solid state fermentation by agricultural and agro-industrial by-products. Brazilian J. Microbiol., 33: 318-324.

Vigneswaran, C., Pavithra, V., Gayathri, V and Mythili, K. 2015. Banana fibre: Scope and value added product developments. J. Textile and Apparel, Technol. Manage., 9(2): 1-7.

\section{How to cite this article:}

Mageshwaran Vellaichamy and Parnavi Vijay Gaonkar. 2017. Biological treatment of Banana pseudostem fibre: Effect on softening and mechanical properties. Int.J.Curr.Microbiol.App.Sci. 6(5): 1268-1274. doi: https://doi.org/10.20546/ijcmas.2017.605.137 